\title{
Sistem Pendukung Keputusan Pemilihan Produk Asuransi Studi Kasus : PT Commonwealth Life Pontianak
}

\section{Decision Support System Insurance Product Selection Case Study : PT Commonwealth Life Pontianak}

\author{
Wahyu Sindu Prasetya ${ }^{1}$, Kusrini ${ }^{2}$, Hanif Al Fatta ${ }^{3}$ \\ 1,2,3 Magister Informatika STMIK AMIKOM Yogyakarta \\ Jl Ring Road Utara, Condongcatur, Sleman, Yogyakarta 55281 \\ wahyusinduprasetya@gmail.com ${ }^{1}$, kusrini@amikom.ac.id ${ }^{2}$, hanif.a@amikom.ac.id ${ }^{3}$
}

\begin{abstract}
Abstrak
Dalam menentukan produk asuransi sering terjadi masalah-masalah yang dihadapi oleh agen asuransi dan calon nasabah, yaitu lamanya proses penentuan produk dan kurangnya pemahaman nasabah terhadap produk yang ditawarkan. Untuk itu diperlukan suatu sistem yang dapat digunakan oleh agen asuransi dalam proses pemilihan produk yang sesuai dengan kriteria calon nasabah. Penelitian ini bertujuan untuk merancang sistem pendukung keputusan pemilihan produk asuransi dengan menggunakan metode AHP dan TOPSIS. Prototype Sistem dibangun menggunakan bahasa pemrograman PHP dan database MySQL. Sistem yang dibangun menghasilkan perangkingan produk asuransi sesuai dengan kriteria dari calon nasabah. Penelitian ini menyimpulkan bahwa perancangan prototype SPK telah dapat dilakukan berdasarkan hasil pengujian menggunakan User Acceptance Test dengan jumlah pertanyaan 8 dan jumlah responden 6 orang dimana rata-rata jawaban adalah 43,73\% responden menjawab setuju dan 56,27\% responden menjawab sangat setuju. Pengujian akurasi sistem SPK dilakukan dengan membandingkan output dari sistem dengan proses prospekting manual dimana diketahui tidak terdapat perbedaan hasil. Untuk penelitian selanjutnya dapat dilakukan penelitian yang berkaitan dengan perhitungan premi asuransi dan uang pertanggungan bagi calon nasabah.
\end{abstract}

Kata kunci-Asuransi, SPK, AHP, TOPSIS

\begin{abstract}
In marketing of insurance products, time and duration to choose product has been a common problem for agent and customer, part of the time delay is due to lack of knowledge and understanding of insurance products offered. Therefore, a decision support system to help both agents and customers choose products according to customer needs and importance criteria is needed. This research's purpose is to design decision support system to help customer and agents determine insurance product choice. AHP and TOPSIS are utilized and prototype is designed using PHP and MySQL. Designed system produced decision support by ranking system according to customers importance criteria. This research concluded that decision support system designed is suitable with user acceptance test (eight question) for six respondents shows that 43,73\% of respondent agree and 56,27\% strongly agree. accuracy test for decision support system is done by comparing manual prospecting and new system which shows no result difference. insurance cost and insurance cover funds are suggested to be included in the next research.
\end{abstract}

Keywords-Insurance, SPK, AHP, TOPSIS 


\section{PENDAHULUAN}

Asuransi merupakan buah pikiran dan akal budi manusia untuk mencapai suatu keadaan yang dapat memenuhi kebutuhannya, terutama sekali untuk kebutuhan-kebutuhannya yang hakiki sifatnya antara lain rasa aman dan terlindung [1]. Asuransi adalah istilah yang digunakan untuk merujuk pada tindakan, sistem, atau bisnis dimana perlindungan finansial (ganti rugi) untuk jiwa, properti, kesehatan dan lain sebagainya [2]. Asuransi menjanjikan perlindungan kepada pihak tertanggung terhadap risiko yang dihadapi perorangan maupun risiko yang dihadapi oleh perusahaan [3]. Asuransi merupakan sarana finansial dalam tata kehidupan rumah tangga, baik dalam mengahadapi risiko mendasar seperti risiko kematian, atau dalam menghadapi risiko atas harta benda yang dimiliki. Demikian pula dunia usaha dalam menjalankan kegiatannya menghadapi berbagai risiko yang mungkin dapat mengganggu kesinambungan usahanya [4]. Banyaknya jenis resiko yang akan muncul dalam kehidupan seseorang menyebabkan banyak pula jenis produk asuransi yang ditawarkan oleh suatu perusahaan asuransi kepada calon nasabahnya. Berbagai macam jenis produk asuransi yang ditawarkan tentunya sering kali membuat binggung calon nasabah asuransi dalam memilih produk asuransi yang akan dimilikinya yang dianggap lebih dibutuhkan. Pelayanan dari agen asuransi tentang informasi produk-produk asuransi yang ada kepada calon nasabah masih membutuhkan waktu yang cukup lama karena banyaknya pertanyaan dari calon nasabah serta banyaknya produk asuransi yang harus dijelaskan kepada calon nasabah. Keterbatasan tenanga kerja/agen asuransi dari perusahaan asuransi untuk melayani setiap pertanyaan-pertanyaan dari calon nasabah juga menjadi kendala perusahaan. Keadaan tersebut membuktikan bahwa dibutuhkan suatu sistem informasi yang dapat membantu agen asuransi dalam proses pemilihan produk asuransi yang sesuai dengan kebutuhan calon nasabah. Dengan adanya pengembangan sebuah sistem dapat membantu pengambil keputusan agar tidak salah atau keliru dalam mengambil keputusan [5].

Sistem informasi yang menyediakan fasilitas untuk melakukan analisis sehingga proses pengambilan keputusan yang dilakukan oleh pelaku bisnis (dalam hal ini pengambil keputusan) menjadi lebih berkualitas dikenal dengan Sistem Pendukung Keputusan atau Decision Support System [6]. Banyak metode yang dapat digunakan dalam merancang Sistem Pendukung Keputusan. Analytic Hierarchy Process (AHP) dan Technique for order preference by similarity to ideal solution (TOPSIS) merupakan contoh metode Multi Attribute Decision Making (MADM) yang dapat digunakan untuk menyelesaikan masalah Sistem Pendukung Keputusan.

Metode AHP adalah metode pengambilan keputusan dan pemecahan masalah yang kompleks dengan inputan data kualitatif penilaian subjektif dari setiap variabel. Bobot yang digunakan pada perhitungan AHP berdasarkan teori pengukuran melalui perbandingan berpasangan yang telah diuji konsistensinya. Metode TOPSIS adalah salah satu metode pengambilan keputusan multi-kriteria yang pertama kali diperkenalkan oleh Yoon dan Hwang pada tahun 1981 [7]. Metode TOPSIS merupakan suatu metode yang didasarkan pada konsep dimana alternatif terpilih yang terbaik tidak hanya memiliki jarak terpendek dari solusi ideal positif $\left(\mathrm{A}^{+}\right)$, namun juga memiliki jarak terpanjang dari solusi ideal negatif $\left(\mathrm{A}^{-}\right)$[8]. Metode AHP digunakan untuk menentukan bobot dari masing-masing kriteria dengan matriks berpasangan dan metode TOPSIS digunakan untuk membuat perangkingan dengan mencari nilai yang memiliki jarak terdekat dengan solusi ideal positif dan jarak terjauh ke solusi ideal negatif [9]. Bila dibandingkan dengan metode evaluasi lainnya, pembobotan dengan metode AHP dan metode TOPSIS terbukti simpel, jelas, dan masuk akal [10].

Studi kasus yang dilakukan pada penelitian ini yaitu pada PT Commonwealth Life Cabang Pontianak yang beralamat di Komp. Ruko A. Yani Mega Mall, Jl. Ahmad Yani Blok G No. 36 Pontianak. PT. Commonwealth Life Cabang Pontianak merupakan salah satu perusahaan asuransi yang bergerak di bidang asuransi jiwa (asuransi manusia). Perusahaan telah berdiri selama 25 tahun dengan tingkat rasio ketahanan modal 739\% (data 2016). Produk-produk asuransi yang di jual berupa produk asuransi jiwa unit link. peneliti akan membangun sistem 
pendukung keputusan pemilihan produk asuransi yang diharapkan dapat membantu pihak asuransi dalam menentukan produk asuransi bagi calon nasabah dengan kriteria-kriteria yang digunakan dalam pemilihan produk asuranasi di PT. Commonwealth Life Cabang Pontianak.

\section{METODE PENELITIAN}

Metodologi penelitian ini penulis menggunakan wawancara, observasi, studi dokumentasi dan pembagian kuesioner untuk mendapatkan informasi yang berkaitan dengan proses ataupun tahap-tahap prospekting bagi calon nasabah. Adapun yang menjadi responden adalah bagian Area Sales Manager dan Agen Asurasi. Wawancara dilakukan untuk memperoleh informasi terkait dengan proses prospeking. Wawancara dilakukan dengan bagian Agen Asuransi dan Area Sales Manager dari PT. Commonwealth Life Cabang Pontianak. Observasi dilakukan untuk mempelajari bagaimana tatacara sistem prospekting, mulai dari komponen yang menjadi poin penting dalam penilaian sampai dengan proses penentuan produk yang tepat bagi calon nasabah. Studi Dokumentasi dilakukan guna memperoleh dokumen-dokumen input dan output serta dokumen pendukung penelitian. Dokumen yang digunakan pada penelitian ini seperti, form data nasabah yang harus di isi dan form polis asuransi. kuesioner yang disebarkan dan digunakan untuk mengukur tingkat kepentingan dari masing-masing kriteria yang ada untuk dijadikan sebuah matriks perbandingan berpasangan serta kuesioner untuk mendapatkan hasil User Acceptance Test dari prototype sistem yang dibangun.

Dalam penelitian ini metode yang diterapkan adalah dengan melakukan tahap-tahap yaitu analisis, desain, pengkodean, dan pengujian. Seperti pada gambar 1 berikut ini

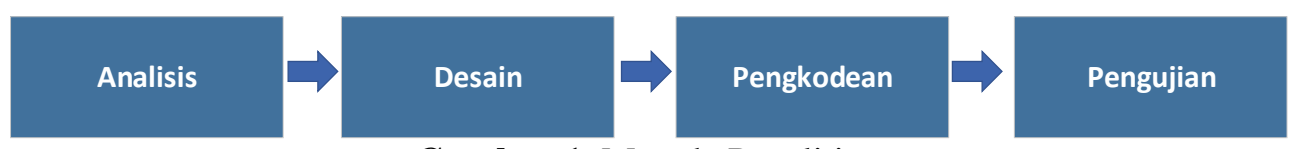

Gambar 1. Metode Penelitian

\section{Keterangan:}

\section{a. Analisis}

Proses pengumpulan kebutuhan yang dilakukan secara intensif untuk mespesifikasikan kebutuhan user agar dapat dipahami perangkat lunak seperti apa yang dibutuhkan oleh user. Pada tahap ini juga dilakukan proses pengumpulan data dan analisis data yang diperlukan dalam perancangan sistem.

b. Desain

Desain sistem adalah proses multi langkah yang fokus pada permodelan sistem dengan metode AHP dan metode TOPSIS dan termasuk juga desain sistem yang meliputi desain proses dengan data flow diagram (DFD), desain Basis Data, dan desain Antarmuka. Tahap ini mentranslasi kebutuhan perangkat lunak dari tahap analisis kebutuhan ke representasi desain agar dapat diimplementasikan menjadi program pada tahap selanjutnya.

c. Pengkodean

Desain harus ditranslasikan ke dalam program perangkat lunak. Pada tahap ini dilakukan implementasi proses desain yang telah dilakukan. Hasil dari tahap ini adalah program komputer sesuai dengan desain yang telah dibuat pada tahap desain.

d. Pengujian

Pengujian fokus pada perangkat lunak dari segi lojik dan fungsional dan memastikan bahwa semua bagian dari segi lojik dan fungsional sudah diuji. Hal ini dilakukan untuk meminimalisir kesalahan (error) dan memastikan keluaran yang dihasilkan sesuai dengan yang diinginkan. Pengujian juga dilakukan untuk mengetahui tingkat keakurasian dari sistem dan tingkat penerimaan terhadap sistem dari calon pengguna. 


\section{HASIL DAN PEMBAHASAN}

\subsection{Analisis}

PT. Commonwealth Life Cabang Pontianak merupakan salah satu perusahaan asuransi yang bergerak di bidang asuransi jiwa. Dalam proses penentuan produk asuransi untuk calon nasabah selama ini dengan cara menjelaskan secara langsung produk asuransi jiwa apa saja yang ada dan di jual pada perusahaan. Proses pengambilan keputusan penentuan produk asuransi bagi calon nasabah dilakukan setelah agen menjelaskan detil produk asuransi, kemudian agen menanyakan informasi detil tentang calon nasabah tersebut. Proses tersebut tentunya kurang efektif karena akan menghabiskan waktu yang cukup lama. Dengan adanya sistem pendukung keputusan pemilihan produk asuransi diharapkan dapat membantu pihak asuransi dalam menentukan produk asuransi bagi calon nasabah dengan lebih cepat dan tepat. Informasi yang dibutuhkan dalam pembuatan sistem diperoleh dengan melakukan wawancara, kuesioner, observasi, dan studi dokumentasi. Data produk asuransi dapat dilihat pada tabel 1

Tabel 1. Data Produk Asuransi

\begin{tabular}{cl}
\hline No. & \multicolumn{1}{c}{ Nama Produk } \\
\hline 1. & Investra Link \\
\hline 2. & Investra Link Ekstra \\
\hline 3. & Investra Titanium \\
\hline 4. & Investra Link Prosper \\
\hline 5. & Investra Platinum \\
\hline 6. & COMM Link \& COMM Link Premier \\
\hline 7. & Maxiwealth Link \\
\hline 8. & Elite Link \\
\hline 9. & Prime Value
\end{tabular}

Kriteria yang digunakan dalam proses pemilihan produk asuransi dapat dilihat pada tabel 2

Tebel 2. Kriteria Pemilihan Produk Asuransi

\begin{tabular}{ccl}
\hline No & Kriteria & \multicolumn{1}{c}{ Nama Kriteria } \\
\hline 1. & C1 & Usia \\
\hline 2. & C2 & Jenis Kelamin \\
\hline 3. & C3 & Pekerjaan \\
\hline 4. & C4 & Pendapatan \\
\hline 5. & C5 & Tinggi \& Berat Badan \\
\hline
\end{tabular}

\subsection{Desain}

Permodelan sistem dalam penelitian ini menggunakan dua metode yaitu AHP dan TOPSIS. AHP digunakan untuk menentukan pembobotan dari setiap kriteria. TOPSIS digunakan untuk melakukan perankingan alternatif produk asuransi.

a. Pembobotan Kriteria dengan model AHP

Langkah pertama dalam menentukan bobot kriteria adalah melakukan perbandingan berpasangan dengan skala satu sampai dengan sembilan. Perbandingan berpasangan tersebut dilakukan dengan membuat matriks perbandingan berpasangan kriteria dimana nilai perbandingan dari setiap kriteria diperoleh dari hasil pembagian kuesioner dan hasilnya seperti ditunjukan pada tabel 3

Tabel 3. Matriks Pebandingan Berpasangan Penentuan Bobot Kriteria

\begin{tabular}{cccccc}
\hline & $\mathrm{C} 1$ & $\mathrm{C} 2$ & $\mathrm{C} 3$ & $\mathrm{C} 4$ & $\mathrm{C} 5$ \\
\hline $\mathrm{C} 1$ & 1 & 2 & 3 & 4 & 5 \\
\hline $\mathrm{C} 2$ & 0,5 & 1 & 2 & 3 & 4 \\
\hline $\mathrm{C} 3$ & 0,3333 & 0,5 & 1 & 2 & 3 \\
\hline $\mathrm{C} 4$ & 0,25 & 0,3333 & 0,5 & 1 & 2 \\
\hline $\mathrm{C} 5$ & 0,2 & 0,25 & 0,3333 & 0,5 & 1 \\
\hline Jumlah & 2,2833 & 4,0833 & 6,8333 & 10,5 & 15 \\
\hline
\end{tabular}

Baris jumlah diperoleh dari penjumlahan nilai setiap kolom. Tahap selanjutnaya adalah melakukan normalisasi matriks dengan membagi angka-angka pada tabel 3 dengan nilai jumlah 
tiap kolom. Nilai baris $\mathrm{C} 1$, kolom $\mathrm{C} 1$ dibagi dengan jumlah kolom $\mathrm{C} 1=1 / 2,2833=0,4380$. Perhitungan dilakukan pada seluruh nilai sehingga mendapatkan matriks ternormalisasi dan dapat di lihat pada tabel 4

Tabel 4. Normalisasi Matriks Perbandingan Berpasangan Penentuan Bobot Kriteria

\begin{tabular}{cccccccc}
\hline & $\mathrm{C} 1$ & $\mathrm{C} 2$ & $\mathrm{C} 3$ & $\mathrm{C} 4$ & $\mathrm{C} 5$ & Jumlah Baris & Prioritas \\
\hline C1 & 0,4380 & 0,4898 & 0,4390 & 0,3810 & 0,3333 & 2,0811 & 0,4162 \\
\hline C2 & 0,2190 & 0,2449 & 0,2927 & 0,2857 & 0,2667 & 1,3089 & 0,2618 \\
\hline C3 & 0,1460 & 0,1224 & 0,1463 & 0,1905 & 0,2000 & 0,8053 & 0,1611 \\
\hline C4 & 0,1095 & 0,0816 & 0,0732 & 0,0952 & 0,1333 & 0,4929 & 0,0986 \\
\hline C5 & 0,0876 & 0,0612 & 0,0488 & 0,0476 & 0,0667 & 0,3119 & 0,0624 \\
\hline Jumlah & 1,0000 & 1,0000 & 1,0000 & 1,0000 & 1,0000 & 5,0000 & 1,0000 \\
\hline
\end{tabular}

Nilai pada kolom prioritas didapatkan dari hasil penjumlahan masing-masing baris dibagi dengan jumlah krieria yang digunakan. Matriks bobot prioritas kriteria dari tabel 4 dapat di lihat secara rinci pada tabel 5

Tabel 4. Prioritas kriteria

$\begin{array}{llllll}\text { Prioritas } & 0,4162 & 0,2618 & 0,1611 & 0,0986 & 0,0624\end{array}$

Langkah selanjutnya adalah mencari konsistensi matriks yang diperoleh dari perkalian matriks perbandingan berpasangan tabel 3 dengan tabel bobot prioritas tabel 4. Matriks konsistensi dapat dilihat pada tabel 5

Tabel 5. Matriks Konsistensi

\begin{tabular}{ccccccc}
\hline Kriteria & C1 & C2 & C3 & C4 & C5 & Jumlah \\
\hline C1 & 0,4162 & 0,5236 & 0,4832 & 0,3943 & 0,3119 & 2,1291 \\
\hline C2 & 0,2081 & 0,2618 & 0,3221 & 0,2957 & 0,2495 & 1,3372 \\
\hline C3 & 0,1387 & 0,1309 & 0,1611 & 0,1971 & 0,1871 & 0,8150 \\
\hline C4 & 0,1041 & 0,0873 & 0,0805 & 0,0986 & 0,1248 & 0,4952 \\
\hline C5 & 0,0832 & 0,0654 & 0,0537 & 0,0493 & 0,0624 & 0,3140 \\
\hline
\end{tabular}

Langkah selanjutnya adalah perhitungan rasio konsistensi dengan cara membagi jumlah matriks konsistensi tabel 5 dengan nilai bobot prioritas tabel 4 . Sehingga perhitungan rasio konsistensinya adalah sebagai berikut:

$\begin{array}{llll}\mathrm{C} 1 & = & 2,1291 / 0,4165 & =5,1154 \\ \mathrm{C} 2 & = & 1,3372 / 0,2618 & =5,1081 \\ \mathrm{C} 3 & = & 0,8150 / 0,1611 & =5,0603 \\ \mathrm{C} 4 & = & 0,4952 / 0,0986 & =5,0234 \\ \mathrm{C} 5 & = & 0,3140 / 0,0624 & =5,0345 \\ & & \text { Jumlah } & =25,3416\end{array}$

Langkah selanjutnya adalah melakukan perhitungan $\lambda$ maks, CI dan CR dimana banyaknya kriteria (n) adalah 5 (lima):

$\lambda$ maks $=\frac{\text { Jumlah }}{n}=\frac{25,3416}{5}=5,0683$

$C I=\frac{(\lambda m a k s-n)}{n-1}=\frac{5,0683-5}{5-1}=\frac{0,0683}{4}=0,0171$

$C R=\frac{C I}{I R}=\frac{0,0171}{1,12}=0,0153$

Berdasarkan perhitungan yang telah dilakukan dimana nilai CR untuk faktor kriteria yang digunakan menunjukkan nilai kurang dari 0,1 maka rasio konsistensinya dapat diterima.

b. Perangkingan Alternatif Produk Asuransi dengan Metode TOPSIS

Metode TOPSIS didasarkan pada konsep bahwa alternatif terpilih yang terbaik tidak hanya memiliki jarak dari solusi ideal positif tetapi juga jarak terpanjang dari solusi ideal negatif [5]. Tingkat kepentingan alternatif terhadap kriteria ditentunkan dengan pemberian nilai 1 sampai 5 seperti terlihat pada tabel 6 
Tabel 6. Ketentuan Rangking Alternatif

\begin{tabular}{clc}
\hline No & \multicolumn{1}{c}{ Keterangan } & Rangking \\
\hline 1. & Sangat Rendah & 1 \\
\hline 2. & Rendah & 2 \\
\hline 3. & Cukup & 3 \\
\hline 4. & Tinggi & 4 \\
\hline 5. & Sangat Tinggi & 5
\end{tabular}

Rating kecocokan dari setipa alternatif produk dengan setiap kriteria yang digunakan dapat di lihat pada tabel 7

Tabel 7. Rating Kecocokan Alternatif pada setiap Kriteria

\begin{tabular}{|c|c|c|}
\hline Kriteria & Rentang Data & Rangking \\
\hline \multirow[t]{5}{*}{ Usia } & $<15$ Tahun & 2 \\
\hline & $15-<25$ Tahun & 4 \\
\hline & $25-<35$ Tahun & 5 \\
\hline & $35-<65$ Tahun & 3 \\
\hline & $>=65$ Tahun & 1 \\
\hline \multirow[t]{2}{*}{ Jenis Kelamin } & Pria & 4 \\
\hline & Wanita & 5 \\
\hline \multirow[t]{5}{*}{ Pekerjaan } & Profesional & 1 \\
\hline & Karyawan & 2 \\
\hline & Wiraswasta & 3 \\
\hline & Pelajar & 4 \\
\hline & PNS & 5 \\
\hline \multirow[t]{5}{*}{ Pendapatan } & $<2,5$ Juta & 1 \\
\hline & $2,5-5$ Juta & 2 \\
\hline & $5-7,5$ Juta & 3 \\
\hline & $7,5-10$ Juta & 4 \\
\hline & $>10$ Juta & 5 \\
\hline \multirow[t]{5}{*}{ Tinggi dan Berat Badan (IMT) } & $<=18.4 \quad-\quad$ (berat badan kurang) & 2 \\
\hline & $18,5-24,9-\quad$ (berat badan ideal) & 5 \\
\hline & $25-29,9-\quad$ (berat badan lebih) & 4 \\
\hline & $30-39,9-\quad$ (berat badan gemuk) & 3 \\
\hline & $>=40 \quad-\quad$ (berat badan sangat gemuk) & 1 \\
\hline
\end{tabular}

Data calon nasabah yang akan digunakan dalam proses perhitungan dapat dilihat pada tabel 8

Tabel 8. Data calon nasabah

\begin{tabular}{|c|c|c|c|c|c|}
\hline \multirow{2}{*}{$\begin{array}{c}\text { Calon } \\
\text { Nasabah }\end{array}$} & \multicolumn{5}{|c|}{ Kriteria } \\
\hline & Usia & Jenis Kelamin & Pekerjaan & Pendapatan & Tinggi \& Berat Badan (IMT) \\
\hline Wahyu & $\begin{array}{l}27 \text { thn } \\
(5)\end{array}$ & $\begin{array}{l}\text { Laki-laki } \\
\text { (4) }\end{array}$ & $\begin{array}{c}\text { Karyawan } \\
\text { (2) }\end{array}$ & $\begin{array}{c}3,6 \mathrm{jt} \\
(2)\end{array}$ & $\begin{array}{c}178 \mathrm{~cm} \& 78 \mathrm{~kg} \\
(5)\end{array}$ \\
\hline
\end{tabular}

Nilai bobot kriteria calon akan di normalisasi dengan nilai bobot prioritas kriteria yang telah diperoleh melalui perhitungan AHP (tabel 4) sebagai berikut:
Usia
Jenis Kelamin
$=(5+0,4162) / 2=2,7081$
Pekerjaan
$=(4+0,2618) / 2=2,1309$
Pendapatan
$=(2+0,1611) / 2=1,0805$
$=(2+0,0986) / 2=1,0493$
Tinggi dan Berat Badan $=(5+0,0624) / 2=2,5312$

Tahap selanjutnya adalah membangun sebuah matriks keputusan alternatif produk berdasarkan rating kecocokan dari setiap alternatif pada setiap kriteria yang dapat dilihat pada tabel 9

Tabel 9. Rating Kecocokan dari Setiap Alternatif pada Setiap Kriteria

\begin{tabular}{lccccc} 
& Usia & $\begin{array}{c}\text { Jenis } \\
\text { Kelamin }\end{array}$ & Pekerjaan & Pendapatan & $\begin{array}{c}\text { Tinggi \& } \\
\text { Berat Badan }\end{array}$ \\
\hline Investra Link & 4 & 5 & 3 & 4 & 4 \\
\hline Investra Link Ekstra & 5 & 4 & 4 & 4 & 3 \\
\hline Investra Titanium & 4 & 5 & 4 & 4 & 3 \\
\hline
\end{tabular}




\begin{tabular}{lcccccc}
\hline & Usia & $\begin{array}{c}\text { Jenis } \\
\text { Kelamin }\end{array}$ & Pekerjaan & Pendapatan & $\begin{array}{c}\text { Tinggi \& } \\
\text { Berat Badan }\end{array}$ \\
\hline Investra Link Prosper & 4 & 4 & 4 & 5 & 3 \\
\hline Investra Platinum & 4 & 5 & 3 & 3 & 4 \\
\hline COMM Link \& COMM Link Premier & 3 & 5 & 5 & 3 & 5 \\
\hline Maxiwealth Link & 4 & 4 & 2 & 2 & 5 \\
\hline Elite Link & 4 & 4 & 5 & 4 & 3 \\
\hline Prime Value & 3 & 5 & 3 & & \\
\hline & {$\left[\begin{array}{lllll}4 & 5 & 3 & 4 & 4 \\
5 & 4 & 4 & 4 & 3 \\
4 & 5 & 4 & 4 & 3 \\
4 & 4 & 4 & 5 & 3 \\
4 & 5 & 3 & 3 & 4 \\
3 & 5 & 5 & 3 & 5 \\
4 & 4 & 2 & 2 & 5 \\
4 & 4 & 5 & 4 & 3 \\
3 & 5 & 3 & 3 & 4\end{array}\right]$}
\end{tabular}

Tahap selanjutnya adalah membuat matriks keputusan ternormalisasi $\mathrm{R}$ dengan perhitungan normalisasi matriks sesuai persamaan 3 [5]

$$
\begin{aligned}
r_{i j}=\frac{x_{i j}}{\sqrt{\sum_{i=1}^{m} x_{i j}^{2}}} \mathrm{R}=\left[\begin{array}{lllll}
0,3393 & 0,3637 & 0,2641 & 0,3651 & 0,3455 \\
0,4241 & 0,2910 & 0,3522 & 0,3651 & 0,2592 \\
0,3393 & 0,3637 & 0,3522 & 0,3651 & 0,2592 \\
0,3393 & 0,2910 & 0,3522 & 0,4564 & 0,2592 \\
0,3393 & 0,3637 & 0,2641 & 0,2739 & 0,3455 \\
0,2545 & 0,3637 & 0,4402 & 0,2739 & 0,4319 \\
0,3393 & 0,2910 & 0,1761 & 0,1826 & 0,4319 \\
0,3393 & 0,2910 & 0,4402 & 0,3651 & 0,2592 \\
0,2545 & 0,3637 & 0,2641 & 0,2739 & 0,3455
\end{array}\right]
\end{aligned}
$$

Tahap selanjutnya adalah membuat matriks keputusan yang ternormalisasi terbobot yang dihasilkan dari matriks ternormalisasi $\mathrm{R}$ dikalikan dengan bobot kriteria dimana bobot kriteria diperoleh dari perhitungan dengan metode AHP bobot calon nasabah yaitu $\mathrm{W}=(2,7081 ; 2,1309$; $1,0805 ; 1,0493 ; 2.5312)$. Contoh perhitungan : $2,7081 * 0,3393=0,9188$. Perhitungan dilakukan hingga keseluruhan nilai dan menghasilkan matriks keputusan yang ternormalisasi terbobot.

$$
Y=\left[\begin{array}{lllll}
0,9188 & 0,7750 & 0,2854 & 0,3831 & 0,8746 \\
0,1485 & 0,6200 & 0,3805 & 0,3831 & 0,6560 \\
0,9188 & 0,7750 & 0,3805 & 0,3831 & 0,6560 \\
0,9188 & 0,6200 & 0,3805 & 0,4789 & 0,6560 \\
0,9188 & 0,7750 & 0,2854 & 0,2874 & 0,8746 \\
0,6891 & 0,7750 & 0,4757 & 0,2874 & 0,0933 \\
0,9188 & 0,6200 & 0,1903 & 0,0209 & 0,0933 \\
0,9188 & 0,6200 & 0,4757 & 0,3831 & 0,6560 \\
0,6891 & 0,7750 & 0,2854 & 0,2874 & 0,8746
\end{array}\right]
$$

Tahap selanjutnya menentukan nilai solusi ideal positif yang dinotasikan dengan $\mathrm{A}^{+}$dan nilai solusi ideal negatif yang dinotasikan dengan $\mathrm{A}^{-}$. Perumusan sesuai dengan persamaan 2 dan 3 [5]

$$
\begin{aligned}
& A^{+}=\left(y_{1}^{+}, y_{2}{ }^{+}, \ldots y_{n}^{+}\right) \\
& A^{-}=\left(y_{1}, y_{2}, \ldots y_{n}^{-}\right)
\end{aligned}
$$




$$
\begin{aligned}
& y_{j}^{+}= \begin{cases}\max _{i} y_{i j} ; & j i k a \mathrm{j} \text { adalah atribut keuntungan } \\
\min _{i} y_{i j} ; & \text { jika } \mathrm{j} \text { adalah atribut biaya }\end{cases} \\
& y_{j}^{-}= \begin{cases}\min _{i} y_{i j} ; & j i k a \mathrm{j} \text { adalah atribut keuntungan } \\
\max _{i} y_{i j} ; & \text { jika } \mathrm{j} \text { adalah atribut biaya }\end{cases}
\end{aligned}
$$

Hasil penentuan solusi ideal positif dan solusi ideal negatif dapat dilihat pada tabel 10

Tabel 10. Solusi ideal positif dan solusi ideal negatif

\begin{tabular}{cccccc}
\hline & $\mathrm{C} 1$ & $\mathrm{C} 2$ & $\mathrm{C} 3$ & $\mathrm{C} 4$ & $\mathrm{C} 5$ \\
\hline $\mathrm{A}+$ & 1,1485 & 0,7750 & 0,4757 & 0,4789 & 1,0933 \\
\hline $\mathrm{A}-$ & 0,6891 & 0,6200 & 0,1903 & 0,1916 & 0,6560 \\
\hline
\end{tabular}

Tahap selanjutnya perhitungan jarak tiap alternatif terhadap solusi ideal positif dan negatif yang dilakukan dengan persamaan 4 dan 5 [5]

$$
\begin{aligned}
D_{i}^{+} & =\sqrt{\sum_{j=1}^{n}\left(y_{i}^{+}-y_{i j}\right)^{2}} ; & i=1,2, \ldots, m . \\
D_{i}^{-} & =\sqrt{\sum_{j=1}^{n}\left(y_{i j}-y_{i}^{-}\right)^{2}} ; & i=1,2, \ldots, m .
\end{aligned}
$$

\begin{tabular}{|c|c|c|}
\hline Altrnatif & $\mathrm{D}^{+}$ & D. \\
\hline Investra Link & 0,3820 & 0,4127 \\
\hline Investra Link Ekstra & 0,4832 & 0,5329 \\
\hline Investra Titanium & 0,5121 & 0,3869 \\
\hline Investra Link Prosper & 0,5264 & 0,4142 \\
\hline Investra Platinum & 0,4165 & 0,3779 \\
\hline COMM Link \& COMM Link Premier & 0,4977 & 0,5531 \\
\hline Maxiwealth Link & 0,4907 & 0,4940 \\
\hline Elite Link & 0,5265 & 0,4134 \\
\hline Prime Value & 0,5760 & 0,3001 \\
\hline
\end{tabular}

Tabel 11. Jarak Alternatif terhadap Solusi ideal Positif dan Negatif

Tahap terakhir adalah menghitung nilai preferensi setiap alternatif dengan persamaan 6 [6]

$$
V_{i}=\frac{D_{i}^{-}}{D_{i}^{-}+D_{i}^{+}} ;
$$

Nilai preferensi dan ranking dari setiap alternatif dapat dilihat pada tabel 12

Tabel 12. Nilai Preferensi Alternatif dan Perangkingan Alternatif

\begin{tabular}{lcc}
\hline \multicolumn{1}{c}{ Altrnatif } & Nilai Preferensi & Rank \\
\hline COMM Link \& COMM Link Premier & 0,5263 & 1 \\
\hline Investra Link Ekstra & 0,5244 & 2 \\
\hline Investra Link & 0,5193 & 3 \\
\hline Maxiwealth Link & 0,5016 & 4 \\
\hline Investra Platinum & 0,4757 & 5 \\
\hline Investra Link Prosper & 0,4403 & 6 \\
\hline Elite Link & 0,4398 & 7 \\
\hline Investra Titanium & 0,4304 & 8 \\
\hline Prime Value & 0,3426 & 9
\end{tabular}

\section{c. Desain Proses}

Dalam penelitian ini pemodelan proses direpresentasikan dengan menggunakan Data Flow Diagram(DFD) dan menggunakan dua jenis DFD yaitu diagram konteks dan diagram level 0 untuk menggambarkan pemodelan proses dari sistem yang akan dibangun.

\section{Diagram Konteks}

Diagram konteks menggambarkan aliran data yang mencakup masukan-masukan dasar, sistem umum dan keluaran serta menunjukan sistem secara keseluruhan. Gambar 2 merupakan diagram konteks dari sistem pendukung keputusan pemilihan produk asuransi yang menggambarkan ruang lingkup dari sistem secara keseluruhan. 


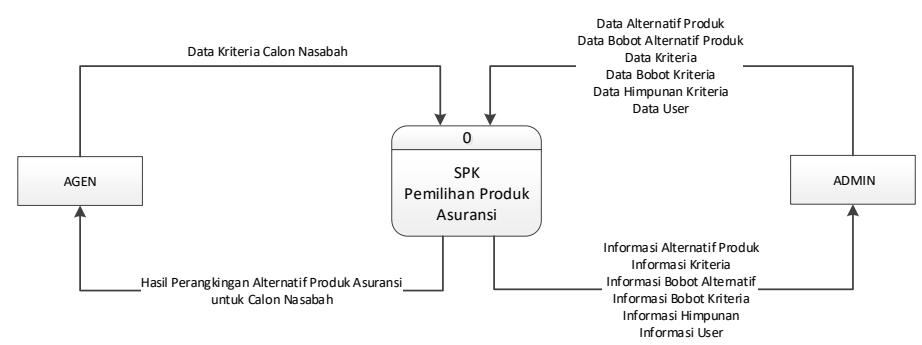

2. Diagram Level 0

Gambar 2. Diagram konteks

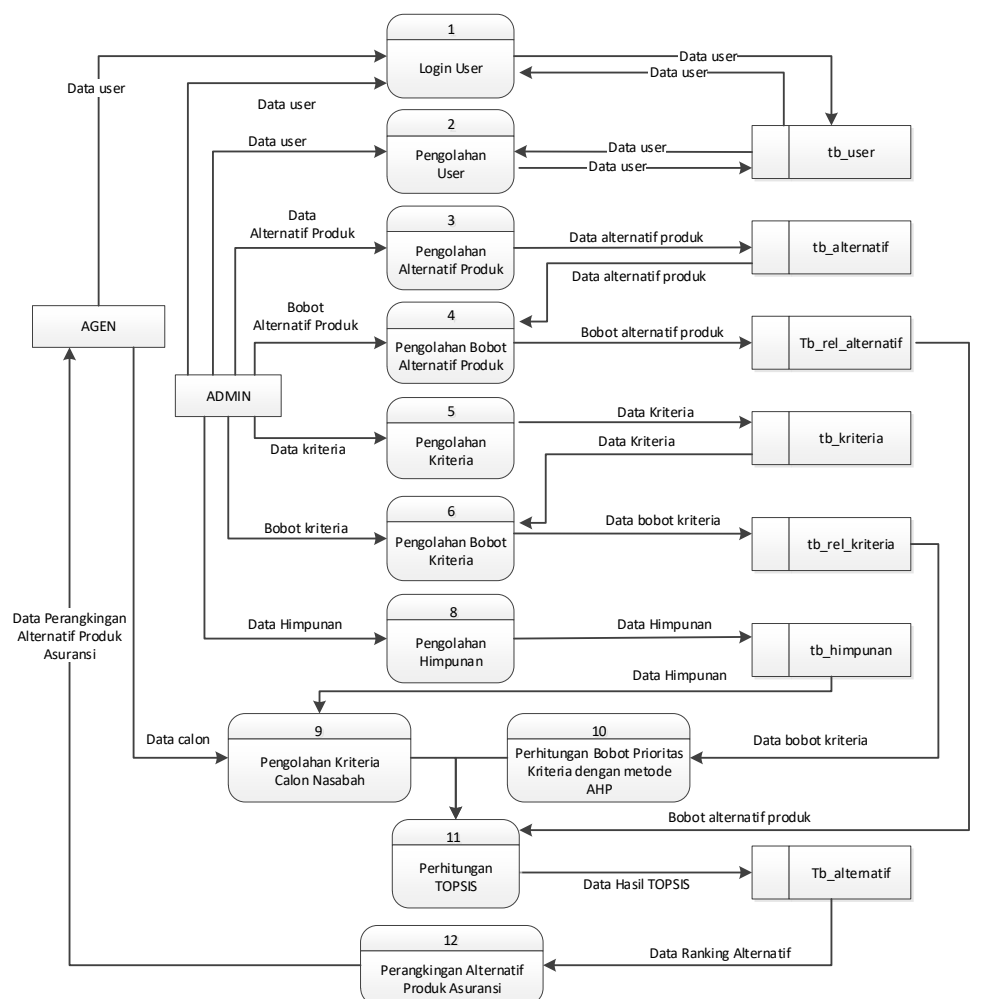

Gambar 3. Diagram Level 0

d. Desain Basis Data

Rancangan relasi data yang akan digunakan pada sistem pendukung keputusan pemilihan produk asuransi dapat dilihat pada gambar 4

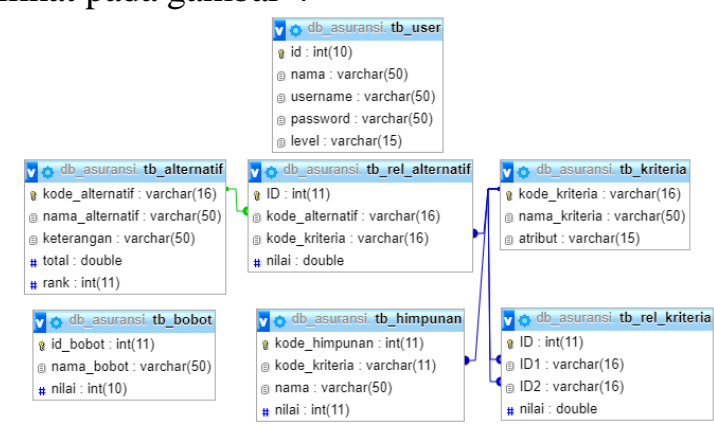

3.3 Implementasi

Gambar 4. Perancangan Relasi Data

Ada enam fungsi utama yang terdapat pada SPK pemilihan produk asuransi antara lain input data kriteria, input matriks berpasangan kriteria, input data alternatif produk asuransi, 
input bobot nilai alternatif produk asuransi, input bobot nilai kriteria calon nasabah, dan perhitungan bobot kriteria serta hasil perangkingan alternatif produk. Berikut implementasi antarmuka SPK pemilihan produk asuransi:

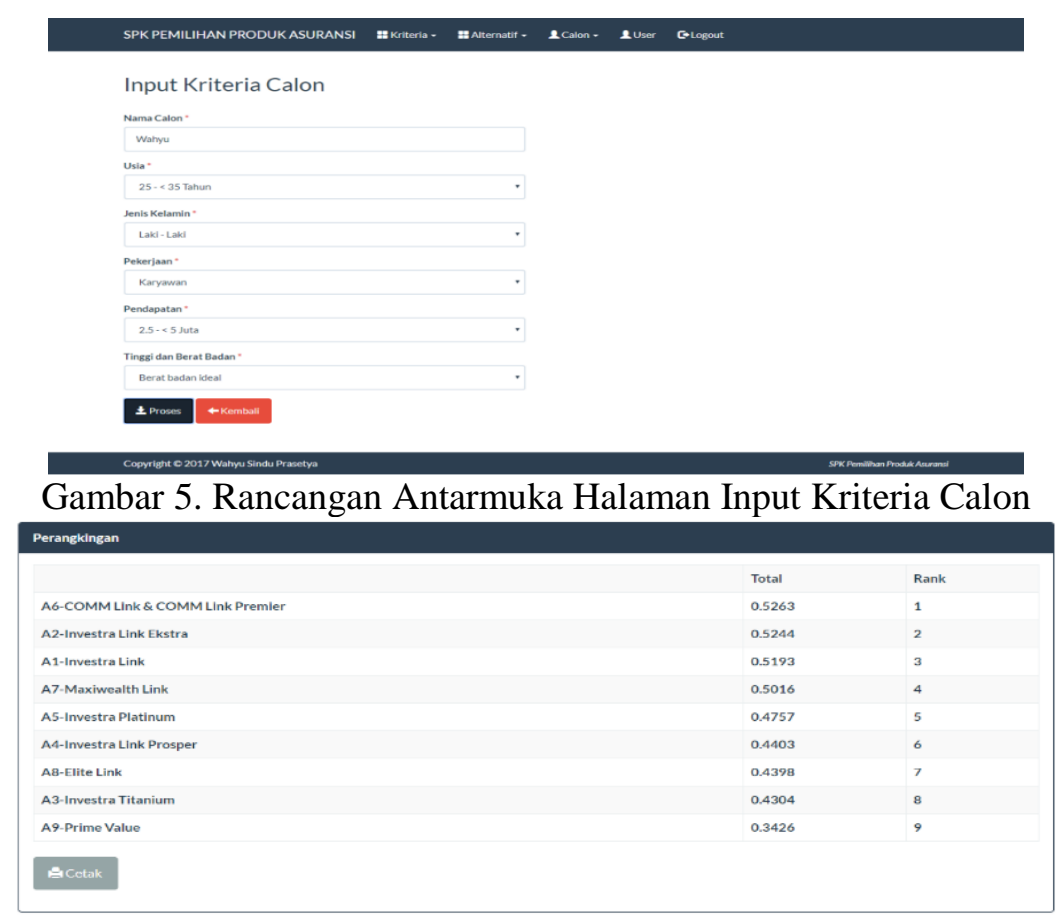

Gambar 7. Rancangan Antarmuka Halaman Perangkingan Alternatif

\subsection{Pengujian}

Pengujian dilakukan dengan tiga cara. Cara pertama adalah pengujian fungsionalitas sistem menggunakan Black Box Testing seperti pada tabel 13 berikut ini

Tabel 13. Pengujian Fungsionalitas

\begin{tabular}{|c|c|c|c|c|}
\hline No & $\begin{array}{l}\text { Komponen } \\
\text { Pengujian }\end{array}$ & Pengujian & Hasil yang diharapkan & $\begin{array}{c}\text { Hasil } \\
\text { Pengujian }\end{array}$ \\
\hline \multirow[t]{3}{*}{1.} & \multirow[t]{3}{*}{ Login User } & $\begin{array}{l}\text { Melakukan proses login sesuai } \\
\text { dengan akun user yang terdaftar }\end{array}$ & $\begin{array}{l}\text { Sistem dapat diakses apabila user berhasil } \\
\text { melakukan proses login }\end{array}$ & Diterima \\
\hline & & $\begin{array}{l}\text { Melakukan proses login dengan } \\
\text { meng-input-kan data password dan } \\
\text { username yang salah }\end{array}$ & $\begin{array}{l}\text { Sistem dapat menampilkan dialog apabila } \\
\text { user salah meng-input-kan username atau } \\
\text { password }\end{array}$ & Diterima \\
\hline & & $\begin{array}{l}\text { Melakukan proses login dengan } \\
\text { akun admin dan agen }\end{array}$ & $\begin{array}{l}\text { Setelah proses login user berhasil sistem akan } \\
\text { menampilkan menu dan halaman sesuai } \\
\text { dengan level user yang melakukan login }\end{array}$ & Diterima \\
\hline \multirow[t]{3}{*}{2.} & \multirow[t]{3}{*}{ Menu Kriteria } & $\begin{array}{l}\text { Melakukan proses tambah, ubah, } \\
\text { dan hapus data kriteria }\end{array}$ & $\begin{array}{l}\text { Sistem dapat melakukan proses tambah, ubah, } \\
\text { dan hapus data kriteria }\end{array}$ & Diterima \\
\hline & & $\begin{array}{l}\text { Memasukkan keyword search } \\
\text { berupa nama kriteria yang akan } \\
\text { dicari pada form pencarian }\end{array}$ & $\begin{array}{l}\text { Sistem dapat melakukan proses pencarian dan } \\
\text { menampilkan hasilpencarian sesuai dengan } \\
\text { keyword yang di inputkan }\end{array}$ & Diterima \\
\hline & & Melakukan cetak data kriteria & Sistem dapat membuat laporan kriteria & Diterima \\
\hline 3. & $\begin{array}{l}\text { Menu Nilai Bobot } \\
\text { Kriteria }\end{array}$ & $\begin{array}{l}\text { Melakukan pengisian bobot kriteria } \\
\text { pada matriks perbandingan } \\
\text { berpasangan kriteria }\end{array}$ & $\begin{array}{l}\text { Sistem dapat melakukan input bobot kriteria } \\
\text { pada matriks perbandingan berpasangan } \\
\text { kriteria }\end{array}$ & Diterima \\
\hline \multirow[t]{2}{*}{4.} & \multirow[t]{2}{*}{ Menu Alternatif } & $\begin{array}{l}\text { Melakukan proses tambah, ubah, } \\
\text { dan hapus data alternatif }\end{array}$ & $\begin{array}{l}\text { Sistem dapat melakukan proses tambah, ubah, } \\
\text { dan hapus data alternatif }\end{array}$ & Diterima \\
\hline & & $\begin{array}{l}\text { Memasukkan keyword search } \\
\text { berupa nama alternatif yang akan } \\
\text { dicari pada form pencarian }\end{array}$ & $\begin{array}{l}\text { Sistem dapat melakukan proses pencarian dan } \\
\text { menampilkan hasil } \\
\text { pencarian sesuai dengan keyword yang di } \\
\text { inputkan }\end{array}$ & Diterima \\
\hline
\end{tabular}




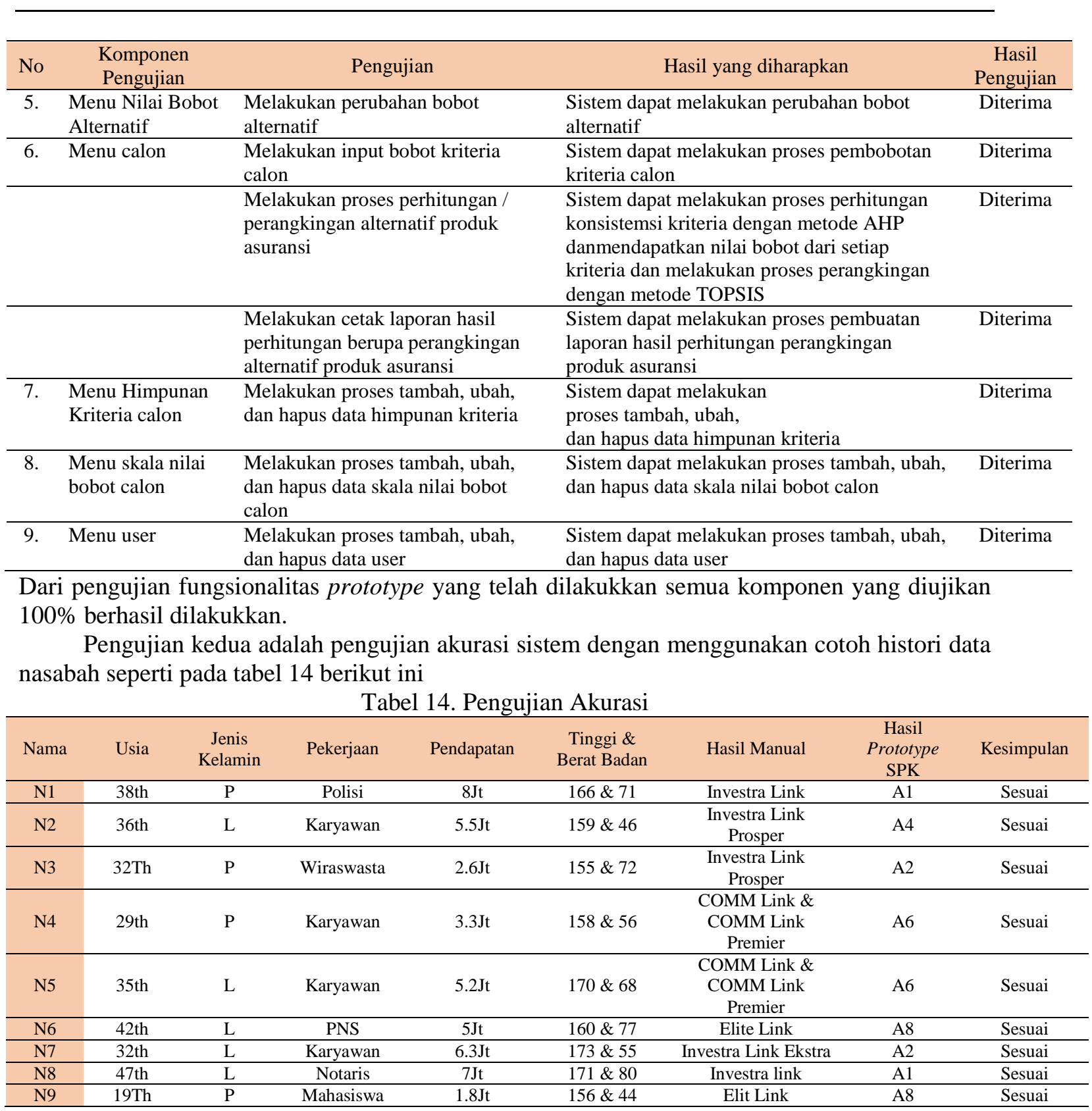

Dari hasil dari pengujian yang dilakukan diketahui tidak terdapat perbedaan antara output prototype sistem SPK dengan hasil proses prospekting secara manual oleh agen asuransi.

Pengujian ketiga menggunakan User Acceptance Test seperti pada tabel 15 berikut ini

Tabel 15. Pengujian User Acceptance Test

\begin{tabular}{|c|c|c|c|c|}
\hline No & Pertanyaan & TS (\%) & S (\%) & SS (\%) \\
\hline 1. & $\begin{array}{l}\text { Prototipe yang dikembangkan dapat digunakan untuk menentukan produk asurnsi bagi calon } \\
\text { nasabah. }\end{array}$ & 0 & 33,3 & 66,7 \\
\hline 2. & $\begin{array}{l}\text { Prototipe memiliki kriteria penilaian yang sesuai dengan penentuan produk asuransi } \\
\text { perusahaan. }\end{array}$ & 0 & 33,3 & 66,7 \\
\hline 3. & $\begin{array}{l}\text { Prototipe memberikan keleluasaan kepada anda untuk melakukan penambahan, perubahan, } \\
\text { dan penghapusan kriteria serta merubah bobot penilaian pada tiap-tiap kriteria. }\end{array}$ & 0 & 50 & 50 \\
\hline 4. & $\begin{array}{l}\text { Prototipe memberikan keleluasaan kepada anda untuk melakukan penambahan, perubahan, } \\
\text { dan penghapusan alternatif produk serta merubah bobot penilaian pada tiap-tiap alternatif }\end{array}$ & 0 & 50 & 50 \\
\hline 5. & $\begin{array}{l}\text { Prototipe memberikan keleluasaan kepada anda untuk melakukan pemberian bobot penilaian } \\
\text { pada calon nasabah. }\end{array}$ & 0 & 50 & 50 \\
\hline 6. & Mudah bagi anda untuk melakukan perubahan bobot pada setiap sesi penilaian. & 0 & 50 & 50 \\
\hline 7. & Setiap perubahan bobot yang anda lakukan menghasilkan keputusan yang sesuai dengan & 0 & 50 & 50 \\
\hline
\end{tabular}


Sistem Pendukung Keputusan Pemilihan Produk Asuransi ...

\begin{tabular}{llrr}
\hline \multicolumn{3}{l}{ perubahan bobot yang dibuat. } & \\
\hline $\begin{array}{l}\text { Peringkat yang dibuat oleh SPK dapat digunakan untuk menentukan produk asuransi bagi } \\
\text { calon nasabah. }\end{array}$ & 0 & 33,3 \\
\hline & Jumlah rata-rata & 66,7 & 43.73 \\
\hline
\end{tabular}

Berdasarkan hasil pengujian dapat disimpulkan bahwa sistem dapat diterapkan dalam pemilihan produk asuransi. Hal ini didasarkan pada nilai rata-rata hasil 43,73\% responden menjawab setuju dan 56,27\% responden menjawab sangat setuju.

\section{KESIMPULAN}

Berdasarkan hasil pengujian menggunakan user acceptance test, prototype yang dikembangkan dapat digunakan untuk menentukan produk asuransi bagi calon nasabah. Hasil perangkingan sistem dapat digunakan sebagai acuan dalam penentuan produk asuransi bagi calon nasabah. Pengujian akurasi prototype sistem dilakukan dengan membandingkan output model dan prototype sistem dengan histori data nasabah bulan November 2017 dan diketahui bahwa tidak terdapat perbedaan hasil antara proses manual dan proses sistem. Pengujian terhadap fungsionalitas sistem dilakukkan dengan metode Black Box Testing dimana semua komponen yang diujikan $100 \%$ berhasil dilakukkan.

\section{SARAN}

Berdasarkan hasil penelitian ini, maka untuk pengembangan selanjunaya dapat dilakukan pengembangan sistem dimana sistem dapat melakukan perhitungan premi asuransi. Dapat juga dilakukan pengembangan sistem dimana sistem dapat melakukan perhitungan dan menampilkan uang pertanggungan yang akan didapatkan bagi calon nasabah.

\section{DAFTAR PUSTAKA}

[1] Darmawi, H., 2006, Manajemen Asuransi, PT. Bumi Aksara, Jakarta.

[2] A Okfalisa, 2014. SIstem Pendukung Keputusan Untuk Menentukan Produk Asuransi Jiwa Bagi Nasabah Menggunakan Metode Smarter. Jurnal Sains, Teknolodi dan Industri, Vol.12, No.1, Desember 2014. Program studi Teknik Informatika UIN SUSKA Riau.

[3] Hartono, S. R., 1992, Hukum Asuransi Dan Perusahaan Asuransi, Sinar Grafika, Jakarta

[4] Sastrawidjaja, M. S., Endang, 1993, Hukum Asuransi, Alumni, Bandung.

[5] Aruan, A., 2014, Sistem Pendukung Keputusan Pemilihan Asuransi Jiwa Menggunakan Metode Fuzzy Multi Criteria Decision Making, Pelita Informatika Budi Darma, 12-15

[6] Kusrini, 2007, Konsep dan Aplikasi Sistem Pendukung Keputusan, Penerbit Andi, Yogyakarta.

[7] Wijaya, K., Wowor, H., Tulenan, V., 2015, Sistem Pendukung Keputusan Penerima Beasiswa dengan Metode Technique for Order Preference by Similarity to Ideal Solution di Universitas Sam Ratulangi Manado, E-journal Teknik Informatika, 1-6.

[8] Kusumadewi, S., Hartati, S., Harjoko, A., 2006, Fuzzy Multi-Attribute Decision Making (Fuzzy MADM), Graha Ilmu, Yogyakarta.

[9] Saptarini, N. G. A. P. \& Prihatini, P. M., 2015, Decision Support System for Scholarship in Bali State Polytechnic Using AHP and TOPSIS, International Conference on Information Technology and Business, 38-46.

[10] Wang, Y., \& Ji, W., 2014, Supermarket Food Safety Evaluation Based on Topsis Method, Second International Conference on Enterprice System, 19-23. 